\title{
RELEVANCE OF BROAD-LEAVED FOREST STANDS FOR MAINTAINING EPIPHYTIC BRYOPHYTE SPECIES AND FUNCTIONAL TRAIT DIVERSITY IN FOREST LANDSCAPE IN LATVIA
}

\author{
Linda Gerra-Inohosa ${ }^{1, \#}$ and Liga Strazdina ${ }^{2}$ \\ ${ }^{1}$ Latvian State Forest Research Institute "Silava", 111 Rīgas Street, Salaspils, LV-2169, LATVIA \\ ${ }^{2}$ Botanical Garden, University of Latvia, 2 Kandavas Street, 2, Rīga, LV-1083, LATVIA \\ \# Corresponding author, linda.gerra@silava.Iv
}

Communicated by Āris Jansons

\begin{abstract}
Broad-leaved trees play an important role in supporting epiphyte richness in deciduous forests. In this study we tested which broad-leaved forest stands in terms of tree composition best predicted biodiversity in regard to bryophyte species number and their functional traits. The bryoflora was surveyed in 70 stands differing in dominant broad-leaved tree species. One circular plot with diameter 30 meters was established in each stand situated in different parts of Latvia. Fifty-three of the plots were located in stands identified as protected habitats of the European Union. In total, 82 bryophyte species were recorded. At plot level the total number of species ranged between 6 and 38 species. Using principal component analysis (PCA), the ordination axes explained $41 \%$ of the variation in composition of bryophytes. The PCA axes were related to tree species composition. The presence of broad-leaved trees, especially ash, lime, and oak, was connected with higher species richness. Generalised linear models confirmed that epiphyte richness, both at the total and indicator species levels, was higher in ash stands. From the functional traits, all expected life-strategy and life-form categories were recorded. The most represented life-forms were smooth mats, tall turfs, and rough mats, while the dominant life-strategy was perennial stayers, followed by competitive perennials and long-lived shuttles. Functional trait richness was highest in Fraxinus excelsior, Tilia cordata, and Quercus robur forest stands.
\end{abstract}

Key words: epiphytes, bryoflora, indicators, tree diversity, life-strategies, life-forms.

\section{INTRODUCTION}

Biological diversity in European forests has become one of the most important subjects in environmental policy (Convention on Biological Diversity, 2020), most likely because of dramatic changes in ecosystems over the last century (Bengtsson et al., 2000). Although broad-leaved forests have been intensively managed in Europe (Dieler et al., 2017), nowadays they still have an important role in conservation of cryptogams (Nordén et al., 2007). Broad-leaved forests are associated with high epiphytic bryophyte species diversity in the boreal coniferous forest landscape (Löbel et al., 2006; Dittrich et al., 2016). The epiphytic species composition and richness in these forests are influenced by various environmental factors. Some of the most significant characteristics are the host tree species and tree size, as well as forest stand quality (Király et al., 2013). In the boreal forest zone, broad-leaved tree species, especially maple and ash, have been associated with the highest epiphytic bryophyte diversity (Snäll et al., 2004; Löhmus et al., 2007).

Studies of species functional traits like life-strategies or life-forms in Latvia (Strazdiṇa et al., 2013; Mežaka and Kirillova, 2019; Ievinsh et al., 2020) and in other countries from the boreal region (Darell and Cronberg, 2011; Michel et al., 2012) have shown that there is different specificity to host tree characteristics and habitat conditions. Some species, especially rare species and indicators of pristine forests, are dependent on large areas of long forest continuity with specific niche abundance (Hedderson, 1992; Söderström, 2006). These species are mostly represented by life- 
forms with complex architecture such as tails, tall turfs, mats, and wefts (Mägdefrau, 1969) and life-strategies such as long-lived shuttles or perennial stayers with limited sporophyte production (During, 1992; Kürschner, 2004). At the same time, other species require only small unmanaged patches or even single trees in managed forest landscapes where they can easily propagate and disperse to the next available niche. Examples of these species represent compact, desiccation tolerant small cushion, short turf and weft life-forms with colonist or pioneer life-strategy properties to produce many spores (Friedel et al., 2006; Patińo et al., 2009; Sporn et al., 2010). These patterns have been explained by bryophyte physiology and adaptation to the four most important factors affecting their growth: light, moisture, substrate, and inter-species relations that are directly linked to bryophyte distribution rates (Bates, 1998; Virtanen, 2014).

There is a need to survey diversity of species in forest ecosystems. Therefore, the aim of this study was, firstly, to determine the epiphytic bryophyte species richness and composition in broad-leaved forests of Latvia, and, secondly, to examine the epiphyte functional trait composition and diversity in broad-leaved forests.

\section{MATERIALS AND METHODS}

Study area. The research area covered the whole territory of Latvia (Fig. 1). Latvia is located in the northern part of Europe in the boreo-nemoral vegetation zone (Sjörs, 1963). The mean annual temperature varies from $4.9{ }^{\circ} \mathrm{C}$ to $7.1{ }^{\circ} \mathrm{C}$ and the mean annual precipitation is from $576 \mathrm{~mm}$ to 757 mm (Avotniece et al., 2017). The greater part of the forest area is dominated by coniferous trees Scots pine Pinus sylvestris and Norway spruce Picea abies. The forests of noble broad-leaved trees occupy only one per cent of the forest area in Latvia (Meža nozare..., 2020).

Field sampling. In total, 70 stands were randomly selected, which ensured representative sampling of eight target tree species in the common noble broad-leaved forest types in Latvia. The studied stands were dominated by different noble broad-leaved tree species - European ash Fraxinus excelsior (18 stands), pedunculate oak Quercus robur (16), small-leaved lime Tilia cordata (11), Norway maple Acer platanoides (9), common hornbeam Carpinus betulus (4), common beech Fagus sylvatica (2), and mixed European white elm Ulmus laevis and wych elm Ulmus glabra forests (10). The age of stands varied from 20 years (maple) to 206 years (oak). The stands represented Aegopodiosa (32 stands), Oxalidosa (17), Hylocomiosa (12), Oxalidosa turf. mel. (4), Filipendulosa (2), Dryopteriosa (1), Myrtillosa mel. (1) and Mercurialiosa mel. (1) forest site types. The majority of studied stands were located on mineral soils (62 stands), four on drained peat soils, two on peat soils, one on wet mineral soils and one on drained mineral soils.

The data were collected during five summer seasons from 2015 to 2019. One circular plot $(\mathrm{D}=30 \mathrm{~m})$ was established

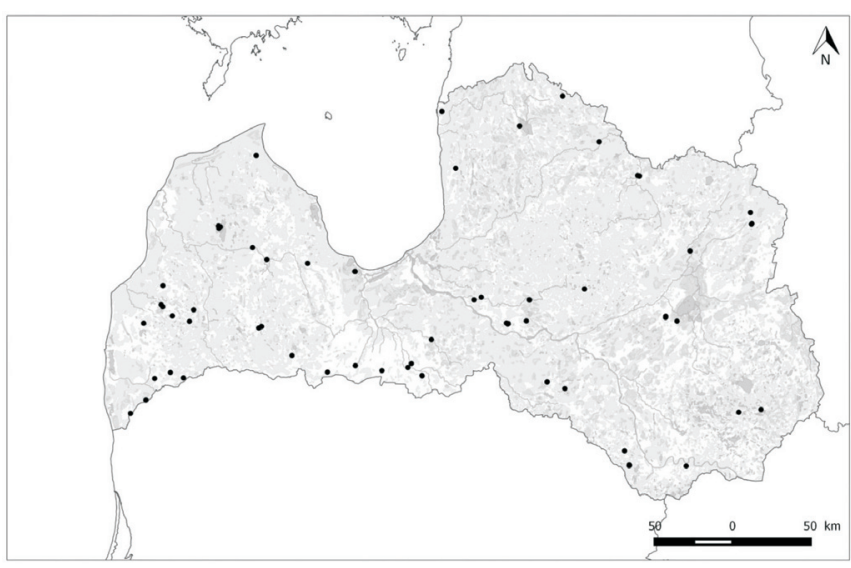

Fig. 1. Location of the studied forest stands in Latvia (plots are marked with black dots).

at randomly chosen coordinates in each of the selected stands. In each plot, five randomly chosen living trees from each tree species were described, recording all bryophyte species found from tree base up to $2 \mathrm{~m}$ height and determining the percentage cover of each epiphyte species. Unknown species were collected and later identified in the laboratory. Nomenclature followed Ābolina et al. (2015). In some plots the minimum number of trees was lacking, and therefore the total number of studied trees was not always constant.

Data analysis. Generalised linear models (GLM) were applied to assess the differences in mean species richness (number of species) per tree among the studied forest stands dominated by different broad-leaved trees (stands of: (1) Tilia cordata, (2) Quercus robur (used as intercept), (3) Fraxinus excelsior, (4) Carpinus betulus, (5) Acer platanoides, (6) mixed Ulmus laevis and Ulmus glabra stands and (7) Fagus sylvatica stands). The Poisson residual distribution and log link were used. To assess the differences in species composition and functional trait diversity in relation to major forest stand variables, we applied principal components analysis (PCA) and indicator species analysis of plots $(n=70)$ (Peck, 2010). The species abundance data were used in the ordination as the species matrix and environmental variables (stand age, forest stand status as EU protected habitat, number of broad-leaved tree species, number of deciduous tree species, bryophyte species richness, number of indicators, life-form richness, life-strategy richness) as the environmental matrix. PCA and Indicator Species Analysis were done in PC-ORD 6 (Peck, 2010), other analyses were performed in $\mathrm{R}$ v. 3.1.2 (A language and..., 2017).

\section{RESULTS}

Species richness. In total, we recorded 82 bryophyte species on the studied trees (Table 1). Epiphytic bryophytes were determined on 19 tree species. Mosses (68 species, $83 \%$ ) contributed to the majority of species richness while liverworts were represented in much lower numbers (14 species, 17\%). Among the recorded bryophytes, 14 
Table 1. Recorded 82 bryophyte species on studied trees $(\mathrm{n}=1034)$ and in the studied plots $(\mathrm{n}=70)$. Bryophyte species trait classification was based on literature: life-forms after Bates (1998), life-strategies after During (1979; 1992), growth forms, gametophyte types, fruiting frequency, fruiting seasons after Bernhardt-Römermann et al. (2018).

\begin{tabular}{|c|c|c|c|c|c|c|c|c|c|}
\hline Bryophyte species & $\begin{array}{c}\text { In studied } \\
\text { stands }\end{array}$ & $\begin{array}{c}\text { On studied } \\
\text { trees }\end{array}$ & $\begin{array}{l}\text { In studied } \\
\text { plots }\end{array}$ & Life-form & Life-strategy & $\begin{array}{c}\text { Growth } \\
\text { form }\end{array}$ & $\begin{array}{c}\text { Gametophyte } \\
\text { type }\end{array}$ & $\begin{array}{l}\text { Fruiting } \\
\text { frequency }\end{array}$ & $\begin{array}{c}\text { Fruiting } \\
\text { season }\end{array}$ \\
\hline Abietinella abietina & $\mathrm{U}$ & 2 & 2 & $\mathrm{~W}$ & $\mathrm{p}$ & $\mathrm{P}$ & $\mathrm{D}$ & $\mathrm{vr}$ & $\mathrm{sp}$ \\
\hline Amblystegium serpens & all & 254 & 47 & $\mathrm{Mr}$ & $\mathrm{p}$ & $\mathrm{P}$ & M & $\mathrm{c}$ & $\mathrm{sp}$ to $\mathrm{a}$ \\
\hline Amblystegium subtile & TFA & 146 & 27 & Ms & $\mathrm{p}$ & $\mathrm{P}$ & M & $\mathrm{c}$ & su to a \\
\hline Amblystegium varium & TQFA & 66 & 22 & Ms & $\mathrm{p}$ & $\mathrm{P}$ & M & o & $\mathrm{sp}$ \\
\hline Anomodon attenuatus* & $\mathrm{FU}$ & 4 & 2 & $\mathrm{Ta}$ & $\mathrm{p}$ & $\mathrm{P}$ & $\mathrm{D}$ & $\mathrm{vr}$ & $\mathrm{a}$ \\
\hline Anomodon longifolius* & TQFCAU & 47 & 15 & $\mathrm{Ta}$ & $\mathrm{p}$ & $\mathrm{P}$ & $\mathrm{D}$ & $\mathrm{vr}$ & a to $\mathrm{w}$ \\
\hline Anomodon viticulosus* & QFCU & 22 & 8 & $\mathrm{Ta}$ & $\mathrm{p}$ & $\mathrm{P}$ & $\mathrm{D}$ & $\mathrm{r}$ & w \\
\hline Atrichum undulatum & QFC & 3 & 3 & $\mathrm{Te}$ & $\mathrm{s}$ & $\mathrm{O}$ & M & $\mathrm{c}$ & $\mathrm{w}$ \\
\hline Blepharostoma trichophyllum & TQF & 3 & 3 & Mt & $\mathrm{c}$ & $\mathrm{P}$ & M & o to $\mathrm{f}$ & $\mathrm{sp}$ to $\mathrm{su}$ \\
\hline Brachytheciastrum velutinum & TQFCU & 34 & 15 & $\mathrm{Mr}$ & $\mathrm{p}$ & $\mathrm{P}$ & M & $\mathrm{f}$ & $\mathrm{w}$ to $\mathrm{sp}$ \\
\hline Brachythecium campestre & $\mathrm{F}$ & 2 & 1 & $\mathrm{Mr}$ & $\mathrm{p}$ & $\mathrm{P}$ & M & & a to $\mathrm{w}$ \\
\hline Brachythecium mildeanum & $\mathrm{U}$ & 1 & 1 & $\mathrm{Mr}$ & $\mathrm{p}$ & $\mathrm{P}$ & M & & \\
\hline Brachythecium plumosum & $\mathrm{F}$ & 1 & 1 & $\mathrm{Te}$ & $\mathrm{p}$ & $\mathrm{P}$ & M & $\mathrm{f}$ & $\mathrm{w}$ \\
\hline Brachythecium rutabulum & all & 384 & 60 & $\mathrm{Mr}$ & $\mathrm{cp}$ & $\mathrm{P}$ & M & $\mathrm{c}$ & a to $\mathrm{sp}$ \\
\hline Brachythecium salebrosum & TQFA & 77 & 27 & $\mathrm{Mr}$ & $\mathrm{p}$ & $\mathrm{P}$ & M & o & a to $\mathrm{w}$ \\
\hline Bryum capillare & $\mathrm{T}$ & 1 & 1 & $\mathrm{CU}$ & $\mathrm{c}$ & $\mathrm{O}$ & $\mathrm{D}$ & $\mathrm{c}$ & sp to su \\
\hline Bryum moravicum & TQA & 4 & 4 & $\mathrm{CU}$ & $\mathrm{c}$ & $\mathrm{O}$ & $\mathrm{D}$ & $\mathrm{c}$ & \\
\hline Calliergonella cuspidata & $\mathrm{F}$ & 2 & 2 & W & $\mathrm{pc}$ & $\mathrm{P}$ & $\mathrm{D}$ & $\mathrm{o}$ & $\mathrm{sp}$ \\
\hline Calypogeia sp. & TQ & 2 & 2 & Ms & $\mathrm{c}$ & $\mathrm{P}$ & $\mathrm{D}, \mathrm{M}$ & $\mathrm{c}$ & $\mathrm{sp}$ \\
\hline Cephalozia bicuspidata & Q & 2 & 1 & Mt & $\mathrm{cp}$ & $\mathrm{P}$ & M & $\mathrm{c}$ & a to $\mathrm{sp}$ \\
\hline Cephaloziella sp. & Q & 1 & 1 & $\mathrm{t}$ & $\mathrm{c}$ & $\mathrm{P}$ & $\mathrm{D}$ & $\mathrm{r}$ & $\mathrm{sp}$ to $\mathrm{su}$ \\
\hline Chiloscyphus pallescens & TQFA & 8 & 6 & Mt & $\mathrm{pc}$ & $\mathrm{P}$ & M & $\mathrm{r}$ to o & $\mathrm{w}$ to $\mathrm{sp}$ \\
\hline Cirriphyllum piliferum & TQFUS & 31 & 17 & Mt & $\mathrm{pc}$ & $\mathrm{P}$ & $\mathrm{D}$ & $\mathrm{r}$ & a to $\mathrm{w}$ \\
\hline Dicranum polysetum & $\mathrm{F}$ & 1 & 1 & $\mathrm{Te}$ & $\mathrm{pc}$ & $\mathrm{O}$ & $\mathrm{D}$ & $\mathrm{r}$ & su to a \\
\hline Dicranum scoparium & all & 49 & 26 & $\mathrm{Te}$ & $\mathrm{cp}$ & $\mathrm{O}$ & $\mathrm{D}$ & $\mathrm{r}$ & su to $\mathrm{w}$ \\
\hline Eurhynchium angustirete & FCAS & 101 & 21 & $\mathrm{Mr}$ & $\mathrm{p}$ & $\mathrm{P}$ & $\mathrm{D}$ & $\mathrm{r}$ to o & a to $w$ \\
\hline Eurhynchium striatum & TQF & 69 & 14 & $\mathrm{Mr}$ & $\mathrm{p}$ & $\mathrm{P}$ & $\mathrm{D}$ & $\mathrm{r}$ to o & a to $\mathrm{w}$ \\
\hline Fissidens adianthoides & $\mathrm{F}$ & 8 & 4 & $\mathrm{Te}$ & $\mathrm{c}$ & $\mathrm{O}$ & $\mathrm{D}, \mathrm{M}$ & $\mathrm{f}$ & a to $\mathrm{sp}$ \\
\hline Fissidens taxifolius & $\mathrm{QF}$ & 2 & 2 & $\mathrm{Te}$ & $\mathrm{c}$ & $\mathrm{O}$ & M & $\mathrm{f}$ & $\mathrm{w}$ to $\mathrm{sp}$ \\
\hline Frullania dilatata & TQFCAS & 76 & 20 & Ms & 1 & $\mathrm{P}$ & $\mathrm{D}$ & $\mathrm{f}$ & a to $\mathrm{sp}$ \\
\hline Frullania fragilifolia & $\mathrm{F}$ & 8 & 2 & $\mathrm{t}$ & 1 & $\mathrm{P}$ & $\mathrm{D}$ & $\mathrm{r}$ & sp to su \\
\hline Frullania tamarisci* ${ }^{*}$ & FC & 5 & 3 & $\mathrm{~W}$ & 1 & $\mathrm{P}$ & $\mathrm{D}$ & o & sp to a \\
\hline Herzogiella seligeri & FU & 2 & 2 & $\mathrm{Mr}$ & ps & $\mathrm{P}$ & M & $\mathrm{c}$ & su \\
\hline Homalia trichomanoides* & all & 343 & 55 & Ms & ps & $\mathrm{P}$ & M & o to $\mathrm{f}$ & $\mathrm{w}$ \\
\hline Homalothecium lutescens & $\mathrm{F}$ & 4 & 3 & $\mathrm{~W}$ & $\mathrm{p}$ & $\mathrm{P}$ & $\mathrm{D}$ & $\mathrm{r}$ & w \\
\hline Homalothecium sericeum & TQFCUS & 20 & 11 & Ms & $\mathrm{p}$ & $\mathrm{P}$ & $\mathrm{D}$ & o & $\mathrm{w}$ \\
\hline Hylocomium splendens & QF & 6 & 3 & W & $\mathrm{pc}$ & $\mathrm{P}$ & $\mathrm{D}$ & $\mathrm{r}$ & $\mathrm{sp}$ \\
\hline Hypnum cupressiforme & all & 597 & 64 & Ms & ps & $\mathrm{P}$ & $\mathrm{D}$ & $\mathrm{f}$ & $\mathrm{a}$ \\
\hline Isothecium alopecuroides* & TQFCS & 40 & 14 & $\mathrm{D}$ & ps & $\mathrm{P}$ & $\mathrm{D}$ & o to $\mathrm{f}$ & a to $\mathrm{w}$ \\
\hline Isothecium myosuroides* & $\mathrm{U}$ & 1 & 1 & $\mathrm{D}$ & $\mathrm{p}$ & $\mathrm{P}$ & $\mathrm{D}$ & $\mathrm{f}$ to $\mathrm{c}$ & w \\
\hline Lejeunea cavifolia* & TQF & 24 & 11 & $\mathrm{t}$ & 1 & $\mathrm{P}$ & M & o & su to $\mathrm{w}$ \\
\hline Lepidozia reptans & $\mathrm{F}$ & 1 & 1 & Mt & $\mathrm{cp}$ & $\mathrm{P}$ & M & o & $\mathrm{w}$ to $\mathrm{su}$ \\
\hline Leskea polycarpa & $\mathrm{T}$ & 3 & 2 & $\mathrm{Mr}$ & $\mathrm{p}$ & $\mathrm{P}$ & M & $\mathrm{c}$ & $\mathrm{sp}$ to $\mathrm{su}$ \\
\hline Leucodon sciuroides & TQFCU & 147 & 28 & $\mathrm{Ta}$ & 1 & $\mathrm{P}$ & $\mathrm{D}$ & $\mathrm{vr}$ & $\mathrm{w}$ to $\mathrm{sp}$ \\
\hline Lophocolea heterophylla & TQFAUS & 52 & 26 & Mt & $\mathrm{cp}$ & $\mathrm{P}$ & M & $\mathrm{c}$ & a to $\mathrm{sp}$ \\
\hline Metzgeria furcata* & all & 92 & 22 & Ms & 1 & $\mathrm{P}$ & $\mathrm{D}$ & $\mathrm{o}$ & $\mathrm{sp}$ to $\mathrm{w}$ \\
\hline Mnium hornum & $\mathrm{QFU}$ & 8 & 8 & $\mathrm{Te}$ & 1 & $\mathrm{O}$ & $\mathrm{D}$ & $\mathrm{f}$ & $\mathrm{sp}$ \\
\hline
\end{tabular}


Table 1. (Continued)

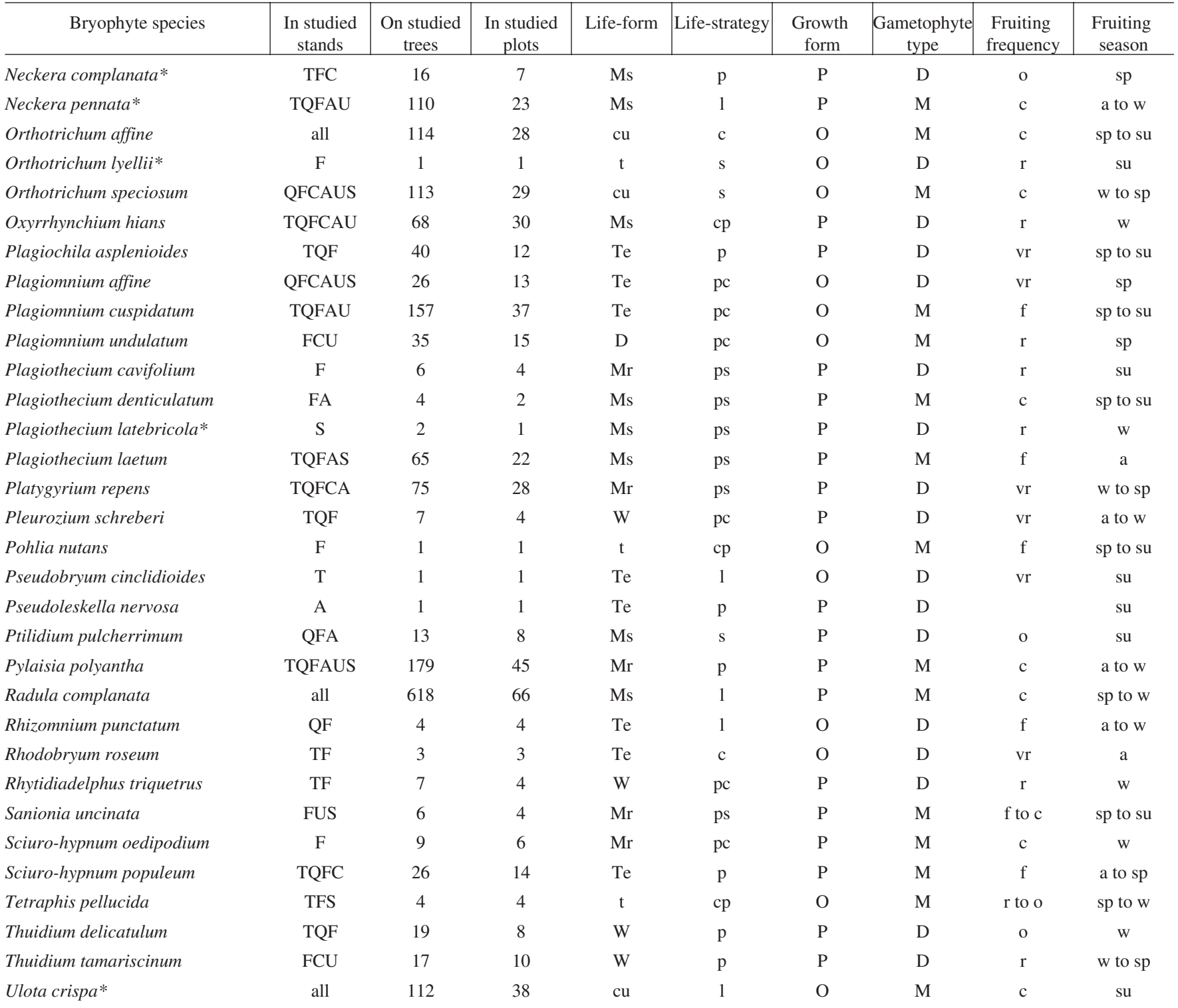

* rare, especially protected, red-listed or woodland key habitat indicator species. Forest stands: T, Tilia cordata; Q, Quercus robur; F, Fraxinus excelsior; C, Carpinus betulus; A, Acer platanoides; U, Ulmus spp.; S, Fagus sylvatica. Life-form: cu, small cushion; CU, large cushion; D, dendroid; Mr, rough mat; Ms, smooth mat; Mt, thread-like mat; t, short turf; Ta, tail; Te, tall turf; Th, thalloid-mat; W, weft. Life-strategy: c, colonist; cp, pioneer; 1, long-lived shuttle; p, perennial stayer; pc, competitive perennial; ps, stress-tolerant perennial; s, short lived shuttle. Growth form: P, plagiotropic; O, orthotropic. Gametophyte type: D, dioicous; M, monoicous. Fruiting frequency: c, common; o, occasional; f, frequent; r, rare; vr, very rare. Fruiting season: sp, spring; su, summer; a, autumn; w, winter.

epiphytic species were red-listed, rare, especially protected or used as woodland key habitat indicators in Latvia (Auniňš, 2013) — Anomodon attenuatus, A. longifolius, A. viticulosus, Frullania tamarisci, Homalia trichomanoides, Isothecium alopecuroides, I. myosuroides, Lejeunea cavifolia, Metzgeria furcata, Neckera complanata, N. pennata, Orthotrichum leyelli, Plagiothecium latebricola, and Ulota crispa. These species were referred to as woodland key habitats (WKH) indicators further in the text.

The ten most common species found in all seven forest stand types were: Amblystegium serpens, Brachythecium rutabulum, Dicranum montanum, Dicranum scoparium, Hypnum cupressiforme, Orthotrichum affine, Radula complanata, and also three indicators Homalia trichomanoides, Metzgeria furcata, and Ulota crispa. The twelve least common species that were found only in one of 70 plots were Brachythecium campestre, Brachythecium mildeanum, Brachythecium plumosum, Bryum capillare, Cephalozia sp., Cephaloziella sp., Dicranum polysetum, Lepidozia reptans, Orthotrichum lyellii, Plagiothecium latebricola, Pohlia nutans, and Pseudobryum cinclidioides.

The total number of species was found to be much higher in the studied Fraxinus excelsior stands (Fig. 2). In addition, the mean number of total epiphytic species per studied plot was greater in the Fraxinus excelsior and Tilia cordata stands (Table 2). Twelve WKH indicators were found on 


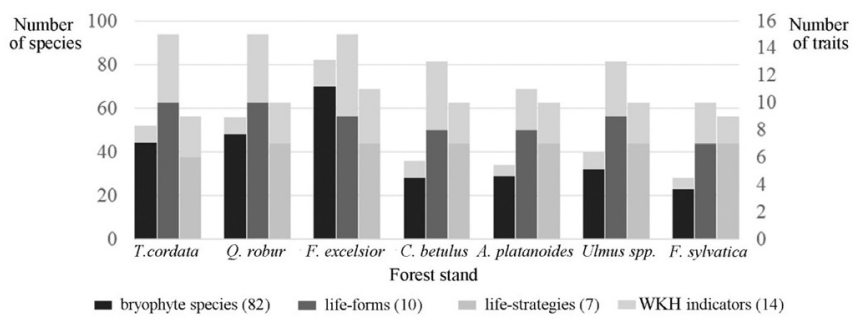

Fig. 2. Total bryophyte species, life-form and life-strategy richness in studied forest stands. Number of woodland key habitats (WKH) indicators for each variable was added on the bars.

Table 2. Mean number of bryophyte species in different forest stands with different dominant tree species. The $p$ value indicates differences between reference and other levels, using generalised linear model (GLM) analysis

\begin{tabular}{|c|c|c|c|}
\hline Studied forest stands & $\begin{array}{c}\text { Number of } \\
\text { studied } \\
\text { forest } \\
\text { stands } \\
\end{array}$ & $\begin{array}{c}\text { Mean number of } \\
\text { epiphytic species } \\
\text { per studied plot } \\
\pm \text { Std. error }\end{array}$ & $p$ value \\
\hline & \multicolumn{3}{|c|}{$\begin{array}{l}\text { All bryophyte } \\
\text { species }\end{array}$} \\
\hline Quercus robur (intercept) & 16 & $13 \pm 0.93$ & 0.001 \\
\hline Tilia cordata & 11 & $16 \pm 1.98$ & 0.001 \\
\hline Fraxinus excelsior & 18 & $24 \pm 1.57$ & 0.001 \\
\hline Carpinus betulus & 4 & $14 \pm 1.03$ & 0.1 \\
\hline Fagus sylvatica & 2 & $16 \pm 1.5$ & 0.05 \\
\hline Acer platanoides & 9 & $14 \pm 1.19$ & \\
\hline \multirow[t]{2}{*}{$\underline{\text { Ulmus laevis, Ulmus glabra }}$} & 10 & $11 \pm 0.91$ & \\
\hline & & \multicolumn{2}{|c|}{$\begin{array}{c}\text { Woodland key habitats (WKH) } \\
\text { indicators }\end{array}$} \\
\hline Quercus robur (intercept) & 16 & $2 \pm 0.30$ & 0.001 \\
\hline Tilia cordata & 11 & $3 \pm 0.71$ & 0.001 \\
\hline Fraxinus excelsior & 18 & $4 \pm 0.57$ & 0.001 \\
\hline Carpinus betulus & 4 & $5 \pm 0.70$ & 0.001 \\
\hline Fagus sylvatica & 2 & $3 \pm 2$ & 0.1 \\
\hline Acer platanoides & 9 & $2 \pm 0.35$ & \\
\hline Ulmus laevis, Ulmus glabra & 10 & $2 \pm 0.54$ & \\
\hline
\end{tabular}

the trees in ash stands, comprising the highest number of epiphytic indicators among all studied stands. Together with Carpinus betulus and Tilia cordata stands, these three forests were characterised by the highest richness of epiphytic WKH indicators. The number of species was related to different forest stands, as significant differences $(p<0.05)$ between stands with different dominant broad-leaved trees were revealed by GLM analysis.

Bryophyte functional traits. In total, bryophytes represented ten different life-forms, of which smooth mats (16 species), tall turfs (16), and rough mats (15) were the most common. This tendency was true also for the indicator species; half of all indicators had a smooth mat or tall turf life-form. The highest life-form richness was recorded in Fraxinus excelsior stands, followed by Tilia cordata and Quercus robur stands (Figs. 2, 3). The cushion form was the least characteristic in the studied forests; the large cushion form was represented only by two species and the small cushion by three species.

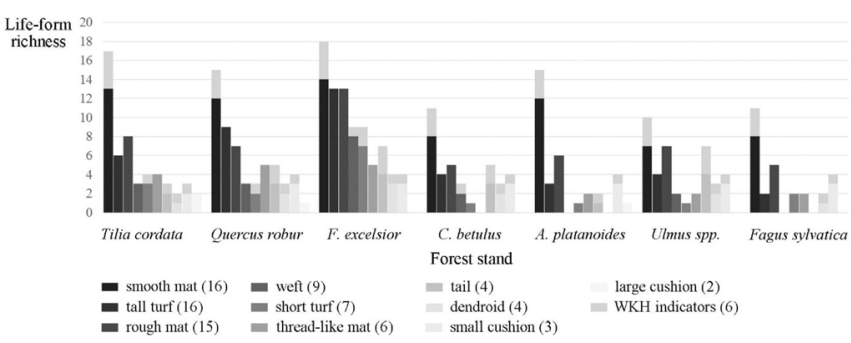

Fig. 3. Life-form richness in different studied forest stands with species number shown in parentheses. Number of WKH indicators representing corresponding life-forms is also given.

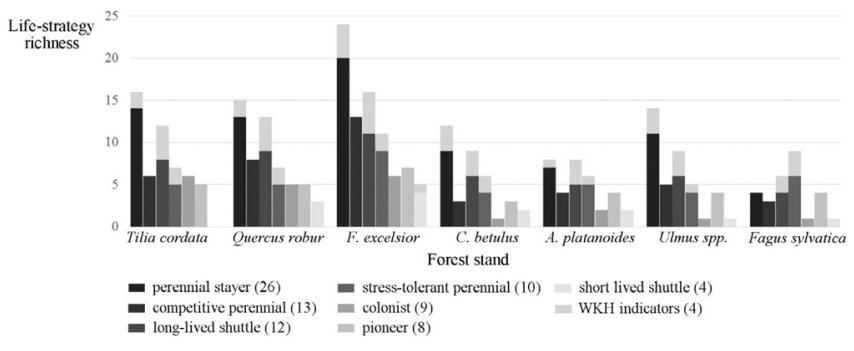

Fig. 4. Life-strategy richness in different studied forest stands with species numbers shown in parentheses. Number of WKH indicators representing corresponding life-forms is also given.

The recorded bryophyte species represented seven life-strategies. The most common strategy with 26 species was perennial stayer, followed by competitive perennials (13 species) and long-lived shuttles (12). Indicators corresponded to four different strategies, from them the long-lived shuttles and perennial stayers were the most common, both represented by five species. Similar to previously described trends, the highest life-strategy richness was recorded in Fraxinus excelsior stands, as well as in Tilia cordata and Quercus robur stands (Figs. 2, 4).

Analysing other bryophyte traits (Table 1), species composition could be divided according to growth form, where the plagiotropic species significantly dominated over oligotrophic species, i.e. 60 to 22 , respectively. Two species groups of similar size were classified depending on gametophyte propagation properties -35 monoicous and 45 dioicous species, plus two species representing both types. Five categories were divided according to fruiting frequency, from which dominated species with common (19 species) or rare (17) development of fruits. Regarding the fruiting season, 13 different types were found. The most common fruiting time in the studied forest stands was winter (13 species), followed by a longer period from autumn to winter (12), and period from spring to summer (11).

Principal component analysis and indicator species analysis. The PCA biplot of bryophyte species composition is shown in Figure 5. Total variance explained by the first pair of axes was $41 \%$. The studied forest plots grouped along axes PC1 and PC2 in the ordination according to bryophyte species composition and dominant tree species in the plot. Negative correlation (Pearson coefficient $\mathrm{r}<-0.6$ ) was found between all biodiversity variables and PC1, except 


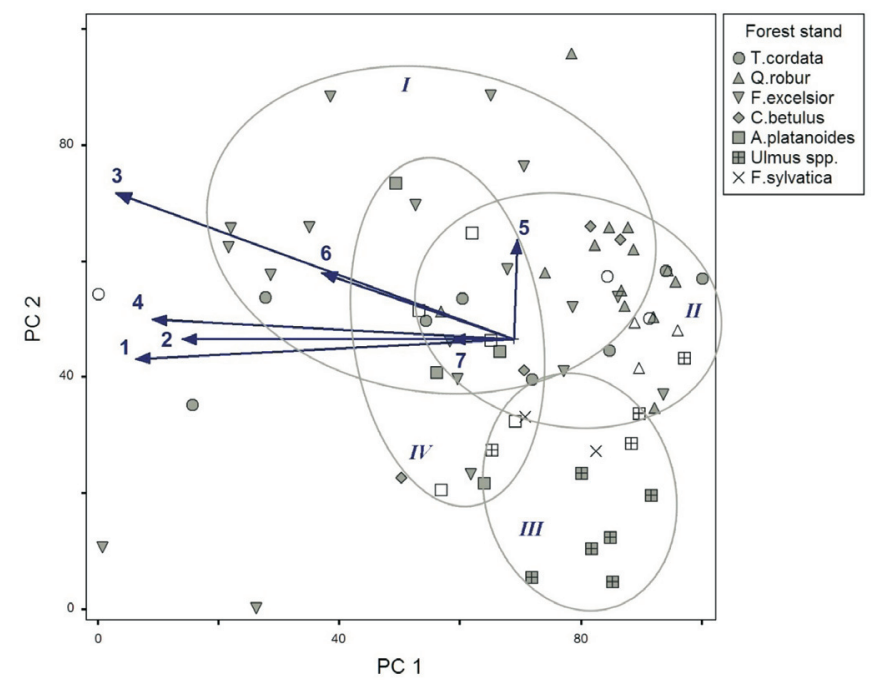

Fig. 5. Principal component analysis of broad-leaved forest stand plots $(\mathrm{n}=70)$ based on abundance data of epiphytic bryophyte species (82 species). Colour of plot symbol shows if it was identified as protected forest habitat of European Union (filled) or not (empty). Clusters of the most influential forest stand plots are marked as follows: Fraxinus excelsior plots (I), joint Tilia cordata and Quercus robur plots (II), mixed Ulmus laevis and Ulmus glabra plots (III), Acer platanoides plots (IV). Eigenvalues of axes: $\mathrm{PC} 1=0.459, \mathrm{PC} 2=0.299$. Explained variation was $41 \% ; p<0.001$. Meaning of numbers on vectors and Pearson correlation is given in Table 3.

for the forest age (Table 3). Four distinct clusters of forest plots were recognised, each of which had an indicator species listed in Table 4. Fraxinus excelsior stands (cluster I) tended to have the highest number of species, including WKH indicators. Bryophyte species like Frullania fragilifolia, Homalothecium lutescens, Lepidozia reptans, Orthotrichum lyellii, and Plagiothecium cavifolium etc. were found only in ash plots. However, no species showed statistically significant relation with Fraxinus excelsior stands (Table 4). Tilia cordata and Quercus robur stand plots formed a joint cluster (cluster II) sharing similar species composition between themselves and partly overlapping also with Fraxinus excelsior stand plots. Examples of species that were common only in all three of these forest stands were Amblystegium varium, Blepharostoma trichophyllum, Brachythecium salebrosum, Eurhynchium striatum, Lejeunea cavifolia, Plagiochila asplenioides, and Thuidium delicatulum. Five species were significantly associated to lime and oak stands. Cluster III belonged to mixed Ulmus laevis and U. glabra stand plots and was associated with species like Abietinella abietina, Brachythecium mildeanum, Herzogiella seligeri, and Isothecium myosuroides. From all species, only Amblystegium serpens was significantly related to Ulmus spp. stands. Cluster IV was formed by Acer platanoides plots, which mostly overlapped with bryophyte communities of the other studied forest stand types. Three species (Amblystegium subtile, Orthotrichum speciosum, and Pylaisia polyantha) were significantly associated to maple stands. According to Indicator Species Analysis, the largest number of indicators was found in the two studied Fagus sylvatica stands (Table 4). Richness of bryophyte species, WKH indicators and functional traits showed positive relationship with stands that
Table 3. Pearson correlations between forest stands, bryophyte species richness and bryophyte functional traits with principal component analysis axes 1 and 2. Used variables 1-6 are shown as numbered vectors in Figure 5 .

\begin{tabular}{lcc}
\hline \multicolumn{1}{c|}{ Group } & PC1 & PC2 \\
\hline 1. No of broad-leaved tree species & -0.647 & -0.145 \\
2. No of deciduous tree species & -0.605 & 0.01 \\
3. Bryophyte species richness & -0.663 & 0.4 \\
4. No of WKH indicators & -0.63 & 0.154 \\
5. Age of forest stand & 0.045 & 0.002 \\
6. Life-form richness & -0.459 & 0.271 \\
7. Life-strategy richness & -0.263 & 0.041
\end{tabular}

$\begin{array}{lcc} & \text { Life-form } & \\ \text { Smooth mat } & -0.621 & 0.316 \\ \text { Tall turf } & -0.427 & 0.507 \\ \text { Rough mat } & -0.497 & 0.262 \\ \text { Weft } & -0.249 & 0.3 \\ \text { Short turf } & -0.419 & 0.437 \\ \text { Thread-like mat } & -0.346 & 0.36 \\ \text { Tail } & -0.404 & -0.298 \\ \text { Dendroid } & -0.203 & 0.233 \\ \text { Small cushion } & -0.157 & -0.137 \\ \text { Large cushion } & 0.032 & -0.007 \\ & & \\ \text { Perennial stayer } & -0.652 & 0.128 \\ \text { Competitive perennial } & -0.374 & 0.496 \\ \text { Long-lived shuttle } & -0.562 & 0.27 \\ \text { Stress-tolerant perennial } & -0.401 & 0.478 \\ \text { Colonist } & 0.005 & -0.096 \\ \text { Pioneer } & -0.325 & 0.319 \\ \text { Short lived shuttle } & -0.167 & 0.083\end{array}$

Table 4. Statistically significant indicator bryophyte species for different forest stand types identified using indicator species analysis

\begin{tabular}{ll|l}
\hline \multicolumn{1}{c}{ Studied forest stands } & \multicolumn{1}{c}{ Bryophyte species } & p value \\
\hline Tilia cordata & Eurhynchium striatum & 0.025 \\
Quercus robur & Brachythecium salebrosum & 0.009 \\
& Eurhynchium angustirete & 0.044 \\
& Plagiomnium undulatum & 0.021 \\
& Sciuro-hypnum oedipodium & 0.045 \\
Carpinus betulus & Isothecium alopecuroides & 0.021 \\
Acer platanoides & Amblystegium subtile & 0.019 \\
& Orthotrichum speciosum & 0.057 \\
& Pylaisia polyantha & 0.03 \\
Elmus laevis, Ulmus glabra & Amblystegium serpens & 0.043 \\
& Cirriphyllum piliferum & 0.046 \\
& Lophocolea heterophylla & 0.046 \\
& Orthotrichum affine & 0.003 \\
& Plagiothecium latebricola & 0.026 \\
& Sanionia uncinata & 0.002 \\
& Tetraphis pellucida & 0.031 \\
& Ulota crispa & 0.029
\end{tabular}



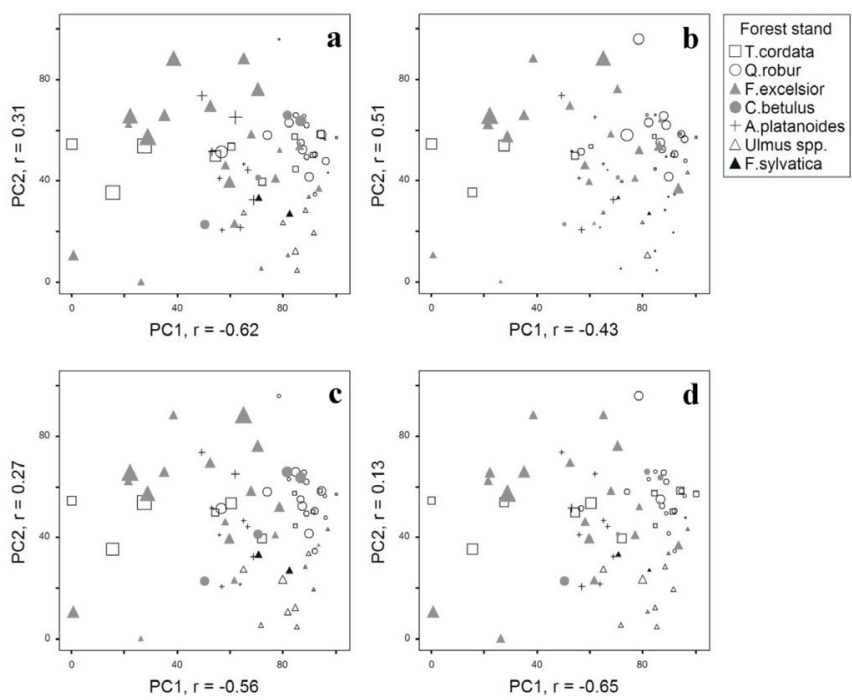

Fig. 6. Principal component analysis of bryophyte functional traits (10 life-forms, 7 life-strategies). Statistically significant correlations $(r< \pm 0.5)$ between PCA ordination axes and bryophyte life-forms: smooth mat (a), tall turf (b), and life-strategies: long-lived shuttle (c), perennial stayer (d). Pearson correlation is given in Table 3.

had been identified as protected forest habitats of European Union.

PCA analysis was used to indicate differences in bryophyte functional trait categories in the studied forest stands. Pearson (r) correlations with the ordination axes were statistically significant only to two of the ten bryophyte life-forms (smooth mat with PC1; tall turf with PC2) and to two of seven life strategies (perennial stayers and long-lived shuttles with PC1) (Table 3, Fig. 6).

\section{DISCUSSION}

The diversity of epiphytic bryophytes was described in broad-leaved forests throughout the territory of Latvia. In our study the seven broad-leaved forest stand types, each with a different dominant tree species, were characterised with epiphyte richness similar to other published studies. For example, Mežaka et al. (2012) reported a total of 73 epiphytic bryophytes in deciduous woodland key habitats. The same number of bryophytes was found in a study by the author in deciduous forest stands in Latvia (Madžule et al., 2012). The results showed that according to species composition, $17 \%$ of all recorded species were rare or protected, and $13 \%$ were indicators of woodland key habitats (Auniņš, 2013). Among them, six bryophyte species - Isothecium myosuroides, Lejeunea cavifolia, Neckera pennata, Neckera complanata, Orthotrichum lyellii, Plagiothecium latebricola - are included in the Red Data Book of Latvia (Liepina, 2017). This may confirm the fact that most of the studied stands represented high-quality habitats with natural forest characteristics (Timonen et al., 2010), which can explain why they were identified as protected habitats of European Union importance. Many authors have also shown that stands with dominating broad-leaved trees have high conservation value in the boreo-nemoral forest region (Ikauniece et al., 2012).
The highest number of all recorded species (85\% from all listed bryophytes) and of WKH indicator species ( $86 \%$ from all recorded indicators) was found in ash stands, while the lowest number of total and WKH indicator species $(28 \%$ and $35 \%$, retrospectively) was recorded in beech stands. In addition, both the results of GLM analysis and PCA ordination indicated that Fraxinus excelsior forests were the species richest stands among all studied plots. We assume that this was due to a higher proportion of ash trees, which are associated with more suitable microhabitats for bryophytes. This is in accordance with the obtained results that the studied ash stands had higher number of rare and especially protected species. However, we did not analyse species composition at tree level. It is well known that of the broad-leaved tree species, European ash is an important substrate providing conditions for a large diversity of epiphytes (Mitchell et al., 2014).

The studied ash stands were characterised with high diversity of different tree species (maximum was five deciduous tree species per studied Fraxinus excelsior plot). It has been shown in other studies that this factor correlates positively with the epiphytic species richness per stand (Lõhmus et al., 2007; Király and Ódor, 2010).

We have to consider that in this survey it was difficult to compare the composition of bryophyte species between forest stand types because of high variability of different characteristics like age or tree layer structure of the studied plots. This also could explain why species composition of Acer platanoides stands was overlapping with bryophyte composition of almost all other studied forest stand types. Although maple is usually related with high species richness in forests, in our study the chosen maple stands represented different ages (from 20 to 124 years). The age variation may be the reason why the species found in maple stands were shared among all other forest types (dominated by the so called generalist species) and also explain the low number of epiphytes in maple plots in general. Additionally it could be related with a low number of deciduous tree species per plot (maximum three species) in the studied maple stands.

Usually a strong positive correlation is found between bryophyte richness and forest age, which is related with tree bark structure (due to increasing roughness with age), substrate longevity and continuity (Friedel et al., 2006; Boudreault et al., 2008; Fritz and Brunet, 2010). However, no correlation with forest age was found in our study. This could be explained by a very diverse tree species composition. All tree species can be arranged by age when they reach best suitability for epiphytes, although it is not always related with age per se. For example, ash and maple are overgrown by bryophytes already when young, as their bark acidity plays a more important role than tree age. However, even old oak and hornbeam trees are poor with epiphytes due to lack of scars on bark. Age might correlate with bryophyte richness within a tree species level but not if different species are compared. 
It is also possible that bryophyte diversity was closely associated with the number of studied stands and trees (Lubek et al., 2019), as some forest types were represented by more than ten plots while others only by less than five plots. However, the average species number per plot in mixed Ulmus spp. or in Acer platanoides stands was similar to species number recorded in Quercus robur stands (oak plots were twice as much represented). It may be that by increasing the number of study plots we would only slightly supplement the species records.

The studied forest stands provided high-quality conditions not only for the epiphyte diversity per se, but also their functional traits. Seven of all known eight life-strategies and ten of all known twelve life-forms were present in the studied plots. The lacking life-forms (thalloid mats characteristic of complex thalloid liverworts and sphagnoids or Sphagnum species) were missing only due to the fact that they are rarely epiphytic. The lacking life-strategy, fugitives, are generally non-existent in stable forest ecosystems. These results suggest a diverse niche abundance in the study sites.

Higher representation of species with more complex life-forms (such as smooth mat, rough mat, tall turf) and long-term life-strategies (like perennial stayer) are consistent with previous studies about bryophyte adaptation to moist microclimate and shadier conditions within unmanaged forest habitats (Strazdina et al., 2013). Fraxinus excelsior, Tilia cordata, and Quercus robur forest stands provided more suitable environment for life-form and life-strategy richness than other stands, most probably due to more diverse tree layer structure and composition, presence of phorophytes of different size and age, as well as stand continuity. Other bryophyte functional traits beside life-strategies and life-forms also showed high diversity, stressing the importance of niches where species with different adaptations to spore distribution time or sporophyte position can coexist together, eliminating inter-species competition for the same resources (Li and Vitt, 1994; Cleavitt, 2002).

\section{CONCLUSIONS}

Our results showed that noble broad-leaved forest stands with high species richness of trees increases the opportunity of higher epiphytic bryophyte species diversity, especially of those species that are closely related to specific microhabitats. In this survey we showed that broad-leaved tree forests are diverse with regard also to bryophyte functional traits. In conclusion, we suggest to ensure the existence of deciduous tree forests with mixed broad-leaved tree species in managed forest landscapes to promote larger epiphyte species diversity. In cases when the broad-leaved forest stands are rich with WKH indicators and correspond to the status of EU forest habitat, we stress that their conservation and protection is crucially necessary to maintain the biological diversity in future.

\section{ACKNOWLEDGMENTS}

This research was funded by JSC "Latvia's State Forests" and LSFRI "Silava" cooperation project "Stabilising role of broadleaved deciduous woodlands in the sustainable forestry in Latvia" (No. 5-5.5_0019_101_16_38).

\section{REFERENCES}

A language and environment for statistical computing (2017). R Core Team. R Foundation for Statistical Computing. http://www.R-project.org (accessed 01.12. 2020).

Āboliṇa, A., Piterāns, A., Bambe, B. (2015). Latvijas kēerpji un sūnas. Taksonu saraksts [Lichens and Bryophytes of Latvia. List of Taxons]. Saule, Daugavpils. 213 lpp. (in Latvian).

Auniņš, A. (Ed.). (2013). European Union Protected Habitats in Latvia. Interpretation Manual. Latvian Fund for Nature, Ministry of Environmental Protection and Regional Development, Rīga. 320 pp.

Avotniece, Z., Aṇiskeviča, S., Maḷinovskis, E. (2017). Klimata pārmaiņu scenāriji Latvijai. Zinojuma kopsavilkums [Climate Change Scenarios for Latvia. Summary]. Latvijas Vides, ǵeoloǵijas un meteoroloǵijas centrs, Rìga. 16 lpp. (in Latvian).

Bates, J. W. (1998). Is 'life-form' a useful concept in bryophyte ecology? Oikos, 82, 223-237.

Bengtsson, J., Nilsson, S. G., Franc, A., Menozzi, P. (2000). Biodiversity, disturbances, ecosystem function and management of European forests. Forest Ecol. Manag., 132, 39-50.

Bernhardt-Römermann, M., Poschlod, P., Hentschel, J. (2018). BryForTrait: A life-history trait database of forest bryophytes. J. Veget. Sci., 29 (4), 798-800.

Boudreault, C., Coxson, D., Vincent, E., Bergeron, Y., Marsh, J. (2008) Variation in epiphytic lichen and bryophyte composition and diversity along a gradient of productivity in Populus tremuloides stands of northeastern British Columbia, Canada. Ecoscience, 15 (1), 101-112.

Cleavitt, N. L. (2002). Stress tolerance of rare and common moss species in relation to their occupied environments and asexual dispersal potential. J. Ecol., 90 (5), 785-795.

Convention on Biological Diversity. Strategic Plan for Biodiversity 2021-2030. (2020).

https://www.cbd.int/doc/strategic-plan/Post2020/Bubb.pdf (accessed 21. 12. 2020).

Darell, P., Cronberg, N. (2011). Bryophytes in black alder swamps in south Sweden: Habitat classification, environmental factors and life-strategies. Lindbergia, 34, 9-29.

Dieler, J., Uhl, E., Biber, P., Müller, J., Rötzer, T., Pretzsch, M. (2017). Effect of forest stand management on species composition, structural diversity, and productivity in the temperate zone of Europe. Eur. J. Forest Res., 136, 739-766.

Dittrich, S., Leuschner, C., Hauck, M. (2016). Change in the bryophyte diversity and species composition of Central European temperate broad-leaved forests since the late nineteenth century. Biodivers. Conserv., 25, 2071-2091.

During, H. J. (1979). Life strategies of bryophytes: A preliminary review. Lindbergia, 5, 2-18.

During, H. J. (1992). Ecological classification of bryophytes and lichens. In: Bates, J. W., Farmer, A. M. (eds.). Bryophytes and Lichens in a Changing Environment. Claredon Press, Oxford, pp. 1-30

Friedel, A., Oheimb, G. V., Dengler, J., Härdtle, W. (2006). Species diversity and species composition of epiphytic bryophytes and lichens: A comparison of managed and unmanaged beech forests in NE Germany. Feddes Repertorium, 117 (1-2), 172-185.

Fritz, Ö., Brunet, J. (2010). Epiphytic bryophytes and lichens in Swedish beech forests: Effects of forest history and habitat quality. Ecol. Bull., 53, 95-107. 
Hedderson, T. A. (1992). Rarity at range limits: dispersal capacity and habitat relationships of extraneous moss species in a boreal Canadian national park. Biol. Conserv., 59, 113-120.

Ievinsh, G., Gaile, L., Elferts, D., Liepina, L. (2020). Relationship between functional traits, functional types, and habitat in boreonemoral bryophytes. Proc. Latvian Acad. Sci., Section B, 74 (3), 196-205.

Ikauniece, S., Brūmelis, G., Zariņš, J. (2012). Linking woodland key habitat inventory and forest inventory data to prioritize districts needing conservation efforts. Ecol. Indicators, 14, 18-26.

Király, I., Nascimbene, J., Tinya, F., Ódor, P. (2013). Factors influencing epiphytic bryophyte and lichen species richness at different spatial scales in managed temperate forests. Biodivers. Conserv., 22, 209-223.

Király, I., Ódor, P. (2010).The effect of stand structure and tree species composition on epiphytic bryophytes in mixed deciduous-coniferous forests of Western Hungary. Biol. Conserv., 143 (9), 2063-2069.

Kürschner, H. (2004). Life strategies and adaptations in bryophytes from the Near and Middle East. Turkish J. Bot., 28, 73-84.

Liepiņa, L. (2017). İpaši aizsargājamās un reti sastopamās sūnu sugas Latvijā [Especially Protected and Rare Bryophyte Species in Latvia]. Latvijas vides aizsardzības fonds, Dabas aizsardzības pārvalde, Daugavpils Universitātes Dabas izpētes un vides izglītības centrs, Rīga. 154 pp. (in Latvian).

Li, Y., Vitt, D. H. (1994). The dynamics of moss establishment: Temporal responses to nutrient gradients. The Bryologist, 97 (4), 357-364.

Löbel, S., Snäll, T., Rydin, H. (2006). Species richness patterns and metapopulation processes: Evidence from epiphyte communities in boreo-nemoral forests. Ecography, 29, 169-182.

Lõhmus, A., Lõhmus, P. (2008). First-generation forests are not necessarily worse than long term managed forests for lichen and bryophytes. Restor. Ecol., 16 (2), 231-239.

Lõhmus, A., Lõhmus, P., Vellak K. (2007). Substratum diversity explains landscape-scale co-variation in the species-richness of bryophytes and lichens. Biol. Conserv., 135, 405-414.

Łubek, A., Kukwa, M., Czortek, P., Jaroszewicz, B. (2020). Impact of Fraxinus excelsior dieback on biota of ash-associated lichen epiphytes at the landscape and community level. Biodivers. Conserv., 29, 431-450.

Madžule, L., Brūmelis, G., Tērauds, A., Zariņš, J. (2012). Time needed to achieve sufficient richness of structural elements and bryophytes in deciduous forest stands. Environ. Exper. Biol., 10, 57-66.

Mägdefrau, K. (1969). Die Lebensformen der Laubmoose. Vegetatio, 16, 285-297.

Meža nozare skaițlos un faktos 2021 (2020). [Forest Sector in Numbers and Facts 2021]. Zemkopības Ministrija. Publishers Zaḷās mājas, Rīga. 53 lpp. (in Latvian).
Mežaka, A., Brūmelis, G., Piterāns, A. (2012). Tree and stand-scale factors affecting richness and composition of epiphytic bryophytes and lichens in deciduous woodland key habitats. Biodivers. Conserv., 21 (12), 3221-324.

Mežaka, A., Kirillova, J. (2019). Epiphytic bryophytes and lichens and their functional trait relationships with host characteristics in the Lüznava Manor Park. Acta Biol. Univ. Daugavp., 19 (2), 241-251.

Michel, P., Lee, W. G., During, H. J., Cornelissen, J. H. C. (2012). Species traits and their non-additive interactions control the water economy of bryophyte cushions. J. Ecol., 100 (1), 222-231.

Mitchell, R. J., Beaton, J. K., Bellamy, P. E., Chetcuti, J., Eaton, S., Ellis, C. J., Gimona, A., Harmer, R., Hester, A. J., Hewison, R. L. et al. (2014). Ash dieback in the UK: A review of the ecological and conservation implications and potential management options. Biol. Conserv., 175, 95-109.

Nordèn, B., Paltto, H., Gotmark, F., Wallin, K. (2007). Indicators of biodiversity, what do they indicate? Lessons for conservation of cryptogams in oak-rich forest. Biol. Conserv., 135, 369-379.

Patińo, J., González-Mancebo, J. M., Fernández-Palacios, J. M. (2009). Epiphytic bryophytes in Canarian subtropical montane cloud forests: The importance of the time since disturbance and host identity. Canad. J. Forest Res., 39, 48-63.

Peck, J. E. (2010). Multivariate Analysis for Community Ecologists: Step-by-Step using PC-ORD. MjM Software Design. Gleneden Beach, Oregon. $162 \mathrm{pp}$.

Sjörs, H. (1963). Amphi-Atlantic zonation, nemoral to arctic. In: Löve, A., Löve, D. (eds.). North Atlantic Biota and Their History. New York, The Macmillan Company, pp. 109-125.

Snäll, T., Hagström, A., Rudolphi, J., Rydin, H. (2004). Distribution pattern of the epiphyte Neckera pennata on three spatial scales: importance of past landscape structure, connectivity and local conditions. Ecography, 27, $757-766$.

Söderström, L. (2006). Conservation biology of bryophytes. Lindbergia, 31, 24-32.

Sporn, S. G., Bos, M. M., Kessler, M., Gradstein, S. R. (2010). Vertical distribution of epiphytic bryophytes in an Indonesian rainforest. Biodivers. Conserv., 19, 745-760.

Strazdina, L., Brūmelis, G., Rēriha, I. (2013). Life-form adaptations and substrate availability explain a 100-year post-grazing succession of bryophyte species in the Moricsala Strict Nature Reserve, Latvia. J. Bryol., 35 (1), $33-46$.

Timonen, J., Siitonen, J., Gustafsson, L., Kotiaho, J. S., Stokland, N. J., Sverdrup-Thygeson, A., Mönkkönen, M. (2010). Woodland key habitats in northern Europe: Concepts, inventory and protection. Scand. J. Forest Res., 25 (4), 309-324.

Virtanen, R. (2012). Diaspore and shoot size as drivers of local, regional and global bryophyte distributions. Global Ecol. Biogeogr., 23, 610-619.

\section{PLATLAPJU MEŽAUDŽU NOZĪME EPIFĪTISKO SŪNU SUGU UN TO FUNKCIONĀLO GRUPU DAUDZVEIDĪBAS VEICINĀŠANĀ LATVIJAS MEŽA AINAVĀ}

Platlapju koku sugas veicina epifìtu bagātību lapu koku mežos. Šajā pētījumā analizēts, kādu platlapju mežaudzes saistītas ar lielāku sūnu sugu un to funkcionālo grupu daudzveidību. Briofloras uzskaite veikta visā Latvijas teritorijā mežaudzēs, kurās dominē septiṇas dažādas platlapju koku sugas. Kopumā ierīkoti 70 apḷveida parauglaukumi $(\mathrm{D}=30 \mathrm{~m})$. No visiem apsekotajiem parauglaukumiem 53 audzes atbilst kādam Eiropas Savienības nozīmes aizsargājamam mežu biotopam. Kopā konstatētas 82 sūnu sugas, to skaits parauglaukumos variēja no 6 līdz 38 sugām. Galvenajā komponentu analīzē ordinācijas asis izskaidroja 41\% no sūnu sugu sadales. Lielāka sūnu sugu bagātība saistīta ar platlapju koku klātbūtni, it īpaši ar osi, liepu un ozolu. Arī vispārējās lineārās analīzes rezultāti rādīja, ka gan kopējais epifītu skaits, gan indikatorsugu skaits bija lielāks ošu audzēs. Pētījumā konstatētas visas mežiem raksturīgās sūnu sugu dzīves stratēǵijas un dzīves formas. Visvairāk pārstāvētās sūnu dzīves formas bija gluds klājiens, augsta velēna un raupjš klājiens. Savukārt no sūnu dzīves stratēǵijām dominēja daudzgadīgi palicēji, daudzgadīgi konkurenti, kā arī daudzgadīgas ceḷotājsugas. 